\title{
Citizens' Continual Usage Intention of Government 2.0 in Nigeria: From Awareness and Perceived Motivation Perspectives
}

\author{
Ogunsola, K. (Ph.D.) \& Olojo, T.P. \\ University of Ibadan \\ Ibadan, Nigeria \\ E-mail: olukemi11@yahoo.com; temmegem@gmail.com \\ Phone: +2348068125011; +2348137699242
}

\begin{abstract}
Government 2.0 involves the use of Web 2.0 technologies by governments to create a transformative opportunity related to key public sector issues such as transparency, collaboration, communication and accountability. Despite its impressive potential, it has hardly been realised yet in practice. This study, thus, investigates the level of awareness of, and perceived motivation towards the use of Government 2.0. The study adopted a survey design approach and collected data using a questionnaire administered to 311 citizens, as respondents who accessed government services via the Facebook and Twitter pages of Federal Inland Revenue Services, and the Federal Road Safety Commission in Lagos and Ibadan, Nigeria. Two research questions were answered using descriptive analysis. Three research hypotheses were tested at 0.05 level of significance, using regression analyses. Findings show that respondents are more aware of the Twitter handle of Federal Inland Revenue Services $(\bar{x}=0.851)$. The findings also revealed that there is a significant influence of citizens' awareness on continual usage intention of Government $2.0\left(\mathrm{~F}=24.757 ; \mathrm{R}=.274 ; \mathrm{R}^{2}=.075 ; \mathrm{p}<.05\right)$, and that there is a significant influence of intrinsic and extrinsic motivation on continual usage intention of Government 2.0 ( $F=86.602, R=.602$; $\left.\mathrm{R}^{2}=.362 ; \mathrm{p}<.05\right)$. The study recommends that motivational incentives, accessibility, open data and shared knowledge should be incorporated into government social media account as this will motivate citizens to use the services continually.
\end{abstract}

Keywords: Digital government, Facebook, Motivation, Nigeria, Twitter, Web 2.0

Journal Reference Format:

Ogunsola, K. \& Olojo, T.P. (2020): Citizens' Continual Usage Intention of Government 2.0 in Nigeria: From Awareness and Perceived Motivation Perspectives. Behavioural Informatics, Digital Humanities \& Development Journal Vol 6. No. 1.Pp 115-135. SMART Research Group, International Centre for IT \& Development (ICITD), Southern University Baton Rouge, LA, USA. @ Creative Research Publishers. DOI: http://dx.doi.org/10.22624/AIMS/BHIN6N2P12

\section{INTRODUCTION}

In recent times, the integration of information communication technologies (ICT) to facilitate services have transformed the manual means of service delivery and communication around the world and has been embraced by individuals, government and private business organisations (Urbina \& Abe, 2017). Governments and public organisations have in the last decade embraced the pronounced use of ICT in delivering effective and efficient services to citizens (Samihah \& Salihu, 2012) through a process referred to as electronic government (egovernment). The evolution of e-government has been studied in different stages and emphasises the connection between governments and the public via digital technologies, which follows four different stages. The first stage of e-government according to Ingrams, Manoharan, Schmidthuber \& Holzer (2017) focuses on building a digital presence, that is, the digitisation of government information. The second stage creates interactions (web-based) of government services with citizens, business organisations and other government agencies through communication platforms that help to provide the information needed. 
The third stage of this electronic system provides online transaction services such as license renewals, permit applications and payments for various government services. These first three stages rely on different information delivery models to bring about fast and convenient access to government information and services across its agencies. The fourth and last stage, which has not yet been fully achieved by many government agencies, requires a meaningful dialogue between the government and the citizens as well as among citizens themselves. This is the stage where the government promotes connected or shared governance to transform how it operates seamless information flow and collaborative decision making using Web 2.0 technologies. The use of Web 2.0 technologies to deliver these government services is referred to as Government 2.0. (Reddick and Aikins, 2012).

The Government 2.0 technology consists of the application of social networking functions and the integration advantages of Web 2.0 to deliver government services. Some of the advantages of the Government 2.0 application is its open, social, communicative, interactive and user-centred functions that has the potential to reshape the relationship between government and citizens; such that services, control and policy formulation are designed with mutual contributions of citizens, governments and civil society. Web 2.0 applications refer to the social networking platforms that enable data sharing in a participatory manner like Facebook, microblogging platforms such as Twitter, other blogging platforms, wikis and media-sharing websites like Flickr and YouTube. (Mergel, Schweik and Fountain, 2009; Meijer, Grimmelikhuijsen and Brandsma, 2012)

Web 2.0 is one major change that has brought transformation to standard workplace practices and more widely to services offered by organisations as a whole (Sivarajah, Irani \& Weerakkody, 2015). According to Kaplan and Haenlein, 2010, the Web 2.0 applications, also called social media, are viewed as more intuitive, user-friendly, user-centred, flexible and less formal than traditional information systems. However, despite the potential to boost the effectiveness of services, the broad use of Government 2.0 is still limited. The knowledge of the factors affecting or limiting its use is important in enhancing its effectiveness and usage. The use of new technologies is supposed to strengthen government legitimacy as well as to boost the efficiency and effectiveness of government policies but there has been no tangible result especially in the developing countries (Eggers, 2004).

This study examined how awareness and perceived motivation influence citizens use of Government 2.0 in two selected government agencies in Nigeria; the Federal Inland Revenue Service (FIRS), and the Federal Road Safety Commission (FRSC). In this study, awareness is defined as the informed interest of citizens to use Government 2.0-compliant government services. Thus, to ensure the effective implementation of Government 2.0, an evaluation of the awareness and perceived motivation by citizens is required. And these are considered important indicators of Government 2.0 successes when used.

Perceived motivation is divided into perceived extrinsic and intrinsic motivations; with extrinsic motivation consisting of attributes of social media and motivation from government service providers such as incentives and accessibility. In this study, the attributes of social media are measured by ubiquity and interactivity. Ubiquity is defined as an apparent presence of new media everywhere at all times. In other words, the frequency by which users are engaged at all times and in different places. Interactivity is defined as the involvement of users in the exchange of information using computers and the rates of the occurrence via online person-to-person or personto-people processes on different websites (Shipps and Philips, 2013). Web 2.0 applications such as social networking sites have become very important as a result of ubiquity and interactivity (Agourram, 2013).

For citizens to use Government 2.0, the government must focus on strategies needed to motivate online users through increasing customers' centricity, providing incentives and improved services (Shao, 2009; Meijer, Koops, Pieterson, Overman and Tije (2012). Although some business organisations use financial incentives to attract consumers, public organisations have to find different ways to encourage and motivate citizens to use social media platforms. In this study, incentive is measured by user-friendliness, social interactions, and selfexpression; as it is assumed that user-friendliness, social interactions, and self-expressions will promote accessibility to Government 2.0 services. 
According to Mandal and McQueen (2012), accessibility has the potential to influence the adoption and use of social networks. Although government institutions frequently try to reach out by using often inaccessible, thirdparty social tools or embed such tools on their websites which produces a negative impact on their functionality (Bertot, Jaeger, Munson and Glaisyer (2010). Governmental agencies need to possess verified accounts to stop spoofing behaviour and guarantee users' access to correct information and services, thus improving citizens' online experiences (Stowe, 2015). In this study, accessibility is measured by the information disseminated, whether it is helpful, reliable, exact/precise, and sufficiently up to date.

Intrinsic motivation is divided into virtual social identity, virtual altruism and virtual telepresence (Kwon \& Wen, 2010). Social identity refers to the ways that people's self-concepts are based on their interest and values (Tajel \& Turner, 1979). Coskunçay (2013) reiterates that a strong social identity reflects the individual interest in technological use for different services, while virtual altruism involves helping people and mutually sharing knowledge for the benefit of others (Chen, 2012). In this study, virtual altruism is measured by the ability of the individual to interact, share knowledge and information on government social media pages. According to Kwon and Wen (2010), virtual telepresence can be considered as a transportation model where there is departure, arrival and return from a facilitated place. In this study, virtual telepresence is measured by individual ability to build virtual networks and community. It is believed that the virtual realm will grow and develop a greater and better dialogue between citizens and governments (Baker, Fairchild, Pater and Seavey, 2010).

The use of Government 2.0 is defined by the frequency of citizens' presence on government websites or social media pages to use services that meet their specific needs. In this study, the use of Government 2.0 is measured by the frequency of citizens' visit, initiation and response tweets and posts on government social media pages. Continual usage intention refers to citizens' intention to continually use or re-use a system. Meijer, Grimmelikhuijsen and Brandsma (2012) argue that societies have undergone several information revolutions whereby changes in information costs, flows, and distributions have impacted the relationship between governments and citizens. These changes work in two directions: first is the effectiveness of mass communication (campaigns) launched by governments to influence citizens' top-down process and, second is the effectiveness of communication and service delivery whereby citizens take the initiative in starting the communication process in a bottom-up process. This study, therefore, intends to respond to the proposition for more demand-side oriented assessments of Government 2.0 and to examine the influences of awareness and motivation on continual usage intention of Government 2.0 by citizens.

\subsection{Statement of Problem}

Since the turn of the new millennium, successive Nigerian governments have embraced the use of ICT in various sectors of the government's affairs. These technologies, to a large extent, have brought about a positive change in government affairs. One of the positive changes created by technology is the introduction of Government 2.0 services. Despite the importance of this emerging trend, identifying and attracting an audience for Government 2.0 services has proved to be a significant challenge in many developing countries (ALotaibi, Ramachandran, Kor and Hosseinian-Far, 2018). According to Aladalah, Cheung and Lee (2015), the figure for public participation in Government 2.0 remains below expectation.

Government 2.0 is a platform that allows citizens' input into the decision making processes and increased transparency by sharing information which offers justifications for government processes and consequently increases citizen satisfaction (Verdegem \& Verleye, 2009). However, studies such as that of AlAwadhi and Morris (2008), Tiamiyu and Ogunsola (2008), Verdegem and Verleye (2009), Alrashidi (2012), and Ogunsola and Tiamiyu (2017) focused on the provision of services through the use of ICT but did not address interactions with citizens using Government 2.0. 
To develop citizens-centred Government 2.0 services that provide accessible and relevant information, the government must first understand the factors that influence citizens' intention to use Government 2.0. Ogunsola and Ojebola (2017) in their study investigated the quality of information disseminated through Facebook by law enforcement agencies in Nigeria. Coskunçay (2013) examined how information quality, system quality, semantic intentions, usability, web page aesthetics, subjective norm and trust affect user satisfaction of Facebook but not the continual usage intention of Government 2.0 services. This study filled this knowledge gap.

Ogunsola and Olojo (2020) examined how trust, and unified theory of acceptance and use of technology (UTAUT) factors; performance expectancy, effort expectancy, and social influence affect citizens' continuance usage intention of Web 2.0. ALotaibi, Ramachandran, Kor and Hosseinian-Far (2018) proposed the use of the UTAUT model, cultural factors identified by the Hofstede model (masculinity, uncertainty avoidance, power distance and collectivism) and factors related to trust and motivational model in the study of citizens' use of Government 2.0. Alrashidi (2012) examined the significance of motivation factors in influencing the use of online government channels. Previous studies have also assessed the roles played by motivation concerning Internet usage, confirming it has had a positive effect on emerging technology use (Stafford and Stern, 2002). Studies (AL-Shehry, Rogerson and Fairweather, 2006; Bwalya and Mutula, 2014; Demircioglua and Chen, 2019) have assessed the part played by either extrinsic or intrinsic factors in motivating users to adopt a technology or use it. Despite the potentials of Government 2.0, studies have overlooked the investigation into citizens' awareness and their motivational factors for using Government 2.0 to access public services. This study thus fills this gap.

\subsection{Research Objectives}

1. to investigate citizens' level of awareness of Government 2.0;

2. to examine the level of perceived citizen's motivation towards continual usage intention of Government 2.0 ;

3. to determine the influence of awareness, perceived motivation, on citizens' continual usage intention of Government 2.0.

\subsection{Research Questions}

1. What is the level of citizens' awareness of Government 2.0?

2. What is the level of citizens perceived motivation towards the use of Government 2.0?

\subsection{Research Hypotheses}

1. Citizens' awareness does not significantly influence their continual usage intention of Government 2.0.

2. Extrinsic motivation (incentives, accessibility, and social media attributes) does not significantly influence citizens' continual usage intention of Government 2.0.

3. Intrinsic motivation (virtual social identity, virtual altruism, and virtual telepresence) does not significantly influence citizens' continual usage intention of Government 2.0.

\section{LITERATURE REVIEW}

\subsection{Pre e-government in Nigeria}

The foundation for Nigeria's political structure was formed from the amalgamation of the Northern and Southern Protectorates of the Niger Area by Lord Fredrick Lugard in 1914 (Isiani \& Obi-ani, 2019). Many decades after, this structure has evolved into a federation of 36 states, with a Federal Capital Territory (FCT), and 774 Local Government Areas (LGAs). Nigeria became Africa's most populous country with nearly 200 million citizens and has developed ICT infrastructure, with Global System for Mobile Communication (GSM) technology as its most dominant communication structure (Bakare, Ekanem and Allen, 2017). 
With the advent of GSM technology in 1999, mobile phone usage began to gain a foothold and gradually became an everyday tool for Nigerians (Bakare, Ekanem and Allen, 2017). However, in addition to the use of the Internet, this allowed Nigerians to gain insight into the dynamics of public governance thus, causing citizens to seek the dividends of governance as experienced by citizens in other countries. The situation of governance in Nigeria became unacceptable as foreign-based Nigerians especially those who are used to the communication systems of developed countries, demanded more interactive avenues from the government in all areas (Abdulkareem, 2016). Unfortunately, poor information dissemination and lack of citizen participation in governance were major banes of the Nigerian government and despite their efforts, the citizens' perception and attitude largely shifted as the government seems to operate without addressing the problems faced by her citizens daily (Ibikunle \& Sarumi, 2012). The implementation of Web 1.0 and Web 2.0 has strengthened the government's reach to the people on many fronts, and as important tools for the delivery of government services to the citizens (lbikunle \& Sarumi, 2012).

\subsection{E-government in Nigeria}

In the early 2000s, the federal government of Nigeria announced the initiative of the government to go digital and concerted efforts were being geared towards the realisation of e-government (Abdulkareem and Ishola, 2016). This was to enhance the operation of the government in providing public service using transparent, effective, efficient means (Abdukareem and Ishola, 2016). Services through e-government were expected to increase transparency, accountability, eliminate hierarchies, and change work practices, work cultures, power structure and employee behaviours by making power more diffused and less concentrated among some small political and administrative elites (Ayoade, 2019).

While many studies such as Kolsaker and Lee-Kelley (2008); Cook (2000); ALotaibi, Ramachandran, Kor and Hosseinian-Far (2018); Tumin and Fung (2010) agrees on e-government being a factor for transparent and accountable government businesses, Bakry (2004) believes that the effects of e-government depend largely on the type of government in operation. This also outlines the United Nations e-government report (2014), which showed that, in addition to the income level of a country, this also contributes towards effective e-government. Nigeria appears not to be in doubt of the efficacy of the implementation of e-government and has made strides however minimal towards making e-government and e-governance a reality in the daily activities of government.

Despite various attempts to improve its e-governance status and nature, United Nations E-Governance Survey Report (2014), still ranks Nigeria among those countries with low e-governance level, ranking $162^{\text {nd }}$ position out of 193 countries. The survey also revealed that Nigeria is among those countries with lower middle income and it had 0.2929 as its e-governance development index figure. Based on the global assessment of Nigeria's growth in online service delivery and telecommunication infrastructures, The UN e-governance survey (2014) placed Nigeria's online service delivery and telecommunication index at 0.3071 and 0.1905 respectively. For governments such as that of Norway, and Australia, their use of Web 1.0 and the successes amassed laid the premises for the implementation of Web 2.0 and the sustenance of e-government. In Nigeria's case, the lack of significant success with Web 1.0 and Government 1.0 has not stopped the government from embracing Government 2.0. Table 1 shows the comparison between e-government (Government 1.0) and Government 2.0.

Table 1: Comparison between E-government and Government 2.0

\begin{tabular}{|l|l|}
\hline \multicolumn{1}{|c|}{ E-government } & Government 2.0 \\
\hline Information provision (information sink) model & Information source (creation) model \\
\hline Service provision model & Service demand model \\
\hline Policy enforcement model & Policy making and negotiation model \\
\hline Agency internal decision making & Shared governance \\
\hline
\end{tabular}

Source: Adapted from Chun, Shulman, Almazan and Hovy (2010) 


\subsection{Government 2.0 and the Benefits}

Mergel, Schweik and Fountain (2009) described Government 2.0 as the use of social networking platforms, content creation and sharing tools, blogs, and microblogging tools within government organisations as well as for interactions with citizens. Chun, Shulman, Almazan and Hovy (2010) referred to Government 2.0 as social media-based digital government. However, for any definition to be satisfactory, it must emphasise the need for citizens to communicate with the government with increased access to information, increased dialogue, and engagement.

The goal of Government 2.0 is to enhance transparency and collaboration between the government and the citizens. It is a shift from publishing to a sharing mindset, one that embraces user participation (Chui, Miller and Roberts, 2009; Dungse, Mato, Makinde and Chidozie (2018). Government 2.0 allows large scale distributed collaboration, information sharing and the creation of collective intelligence in government areas from local to federal levels (Chun, Shulman, Almazan and Hovy, 2010).

The main benefit that Government 2.0 brings is its boundary-breaking potential: truly allowing working anywhere, anytime basis and helping to create a truly integrated digital nervous system for government. As a result of its immediacy and convenience, it also reduces the barriers to public service operations, encouraging citizens or service providers to make use of the technology where previously barriers do exist (Lallana, 2008). According to Chun, Shulman, Almazan and Hovy (2010), the benefits of Government 2.0 are summarized as follow:

- Improving the delivery of government information and services: Government 2.0 can deliver data and services whenever and wherever the citizens are. This enables the citizens to gain immediate access to government information whenever they want to. It is also useful to governments for sending terror alerts or other real time security information.

- Increasing channels for public interactions: Government 2.0 provides an additional channel for interactions between stakeholders in governance such as service providers, policy makers, service consumers, and civil society representatives.

- Lower costs leading to higher participation: the hope concerning the political process is that, by reducing the time and effort of communication, Government 2.0 will encourage more communication, from evoting to contributions to political debates, to complaints or queries.

It has been discovered that the benefits of Government 2.0. are huge, yet many governments in developing countries have not fully tapped these benefits (ALotaibi, Ramachandran, Kor and Hosseinian-Far, 2018). There is a need to motivate stakeholders to embrace the use of Government 2.0

\subsection{Extrinsic Motivation for Government 2.0}

The extrinsic motivation was defined by London (2009) as performing a task or action because it will lead to a separable outcome. This means that people perform some tasks to get encouraged or earn rewards from them, not only because they are enjoying the task. Extrinsic motivation is measured by incentives and accessibility, while Social Media attributes are key factors of Government 2.0 services and interactions. Incentives are referred to as inciting to action, something that encourages a person to do or use something. With Government 2.0, incentives can be defined as an interactive platform that encourages citizens' to use Government 2.0 platforms. Although business organisations use financial incentives to attract consumers, public administration, conversely, has to find different ways to encourage and motivate citizens and business organisations to use their social media platforms. Business organisations give rewards such as loyalty points, and freebies to customers (Margetts and Yared, 2003). 
Accessibility refers to being easily reached, making it easy to obtain information or use information. Governmental bodies at times try to reach out to citizens using third-party social tools, trying to embed such tools on their websites which results in a negative impact on their functionality. This creates disagreement between access, strategy and social media tradition. Emphasis must then be placed on developing policies that give priority to the global usability of government social media platforms, ensuring equal access for all people globally (Bertot, Jaeger, Munson and Glaisyer (2010). Mandal and McQueen (2012) believe that access has considerable influence as regards accepting social media such as Facebook. According to Stowe (2015), accessibility makes citizens' experiences to be better.

Attributes of Social Media such as ubiquity and interactivity are very important parts of social media (Agourram, 2013). Ubiquity is the presence of social media everywhere and at all the time. In other words, it is how it engages users at all times and places (Naeem, 2014). Interactivity on the other hand is defined as the involvement of users in the exchange of information with computers and the degree to which this happens. This is facilitated via online person-to-person or person-to-people processes utilising several different websites (Shipps and Philips, 2013).

\subsection{Intrinsic motivation for Government 2.0}

Intrinsic motivation happens when people engage in several different behaviours that drive playful, exploratory reasons or reasons stemming from curiosity, without any particular incentive or recompense (Ryan and Deci, 2000). Intrinsic motivation in this study is measured by virtual social identity, virtual altruism and virtual telepresence. Virtual social identity refers to a reflection of individual interest in technological use for different government services which must give citizens a reason to build strong social identity through system quality demonstrating usability, ease of use, quality documentation, system flexibility, reliable and loyal services (Coskunçay, 2013).

Virtual altruism has been classified into two types: Kin altruism and reciprocal altruism. Kin altruism occurs between people who are related by blood, while reciprocal altruism relates to non-relatives who have decided to exchange favours (Humphrey, 1997). According to Ramírez-Correa, Rondán-Cataluña and Arenas-Gaitán, (2013), using social media in a government context, kin selection can be ruled out. Reciprocal altruism involves helping other individuals in the hope of reciprocation. In IT contexts, altruistic people are willing to share knowledge to help others (Chen, 2012). Altruistic actions are, according to Fang and Chu (2010), a significant indicator of the intention to distribute knowledge, and those individuals who portray altruistic behaviour are always keen to distribute knowledge in a virtual community. In the government context, reciprocal altruism is establishing trust between social media users C2C (Citizen-to-Citizen), and C2G (Citizen-to-Government). Virtual telepresence on social media can be considered as transportation that shows departure, arrival and returns from a place facilitated by technology. Some academics believe that the virtual realm will grow and develop a dialogue between citizens and governments (Baker, Fairchild, Pater and Seavey, 2010).

\section{METHODOLOGY}

The study adopted a descriptive survey design. The study was limited to Lagos and Ibadan which are the largest cities in Southwestern Nigeria in terms of population. The study population consisted of citizens (followers) who frequent social media platforms of the Federal Road Safety Commission (FRSC) and the Federal Internal Revenue Services (FIRS) such as Twitter and Facebook. The questionnaire used for data collection was developed by the researchers, and a reliability test was conducted on the instrument using Cronbach alpha to determine the internal consistency of the multiple items as shown in Table 2. 
Table 2: Cronbach Alpha Result of Test of Instrument

\begin{tabular}{|l|l|l|l|l|}
\hline Section & Variable or Construct name & No. of items & Cronbach Alpha & Comment \\
\hline 1 & Continual usage intention of Government 2.0 & 3 & 0.909 & Good \\
\hline 2 & Awareness & 4 & 0.812 & Good \\
\hline 3 & Perceived motivation towards using Government 2.0 (Extrinsic Motivation) \\
\cline { 2 - 5 } & a. Incentives & 4 & 0.769 & Good \\
\cline { 2 - 5 } & b. Accessibility & 6 & 0.886 & Good \\
\cline { 2 - 5 } & c. Social Media Attribute & 6 & 0.793 & Good \\
\cline { 2 - 5 } & i. Ubiquity & 5 & 0.850 & Good \\
\cline { 2 - 5 } & ii. Interactivity & 5 & 0.751 & Good \\
\hline 4 & Perceived motivation towards using Government 2.0 (Intrinsic Motivation) \\
\cline { 2 - 5 } & a. Virtual Social identity & 5 & 0.854 & Good \\
\cline { 2 - 5 } & b. Virtual Altruism & 3 & 0.797 & Good \\
\cline { 2 - 5 } & C. Virtual Telepresence & \multicolumn{2}{|l}{} \\
\hline
\end{tabular}

The data collected from the field was coded and analysed using the Statistical Package for Social Sciences (SPSS) version 23. Purposive sampling technique was used to select two offices of the FRSC, and one office of FIRS in Lagos, while one office of FRSC and one FIRS office were selected in Ibadan. These offices were selected due to their high level of engagement with citizens. To get a sample frame of customers at the two agencies, a pre-study visit was made to the offices where enquiries were made. According to data obtained from the record book of the agencies, on weekly basis, an estimated average number of citizens applying for services at FRSC offices were 1990 users, and 1025 users from FIRS. Therefore, the targeted population consists of an estimate of 3015 citizens' who visit the offices to obtain services. Out of this population, the purposive sampling technique was used to select the followers of the agencies on social media (Facebook and Twitter users) as the respondents for the study. Respondents' consent was sought before they were involved in the study. They were also asked if they have used any one of the agencies' Twitter handle or Facebook page before. This was to ensure the respondents were actual users of Government 2.0 services of the agencies.

According to Nwana (1981), for a population of a few thousand; a sample size of $10 \%$ is satisfactory; and Gay and Airasian (2003), which says that beyond a certain point, at about 5000 or more, population size is almost irrelevant and a sample size of about 400 should be adequate. Therefore 400 copies of the questionnaire were distributed but 311 copies were retrieved and found useable for the study. This represented $77.8 \%$ of the sample. Descriptive statistics such as percentages, and mean were used to analyse responses from the research questions.

For awareness, the responses were based on "Yes" and "No" options. The mean score was calculated for each question. The mean score was computed using 1 as the highest score. The closer the mean is to 1 , the higher the level of awareness and the farther the mean is from 1; the lower the level of awareness of Government 2.0 by the respondents. For extrinsic and intrinsic motivation, as well as citizens' continual usage intentions of Government 2.0, respondents were asked to rate on a 4-point scale with 1 as strongly disagree to 4 as strongly agree (i.e. Strongly disagree $=1$, Disagree $=2$, Agree $=3$ and Strongly agree $=4$ ). Regression analysis was used to determine the influence of the independent variables on the dependent variable. 


\section{RESULTS AND DISCUSSIONS}

\subsection{Demographic Statistics}

Out of a total of 311 respondents, $174(55.9 \%)$ male respondents, as well as, $137(44.1 \%)$ female respondents participated in the study, see Figure 1.

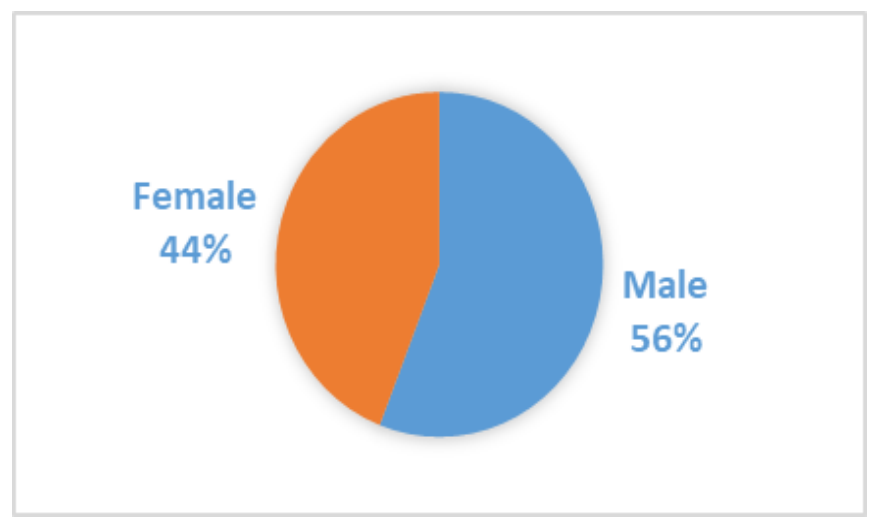

Figure 1: Sex of Respondents

For the level of education of the respondents, $11(3 \%)$ respondents had Ph.D. degree, $82(27 \%)$ respondents had Master's degree, 159 (52\%) respondents had Bachelor degree (B.Sc.) or Higher National Diploma (HND), with the remaining $56(18 \%)$ respondents having Nigeria Certificate in Education (NCE) or Ordinary National Diploma (OND) as their highest educational qualification, see Figure 2.

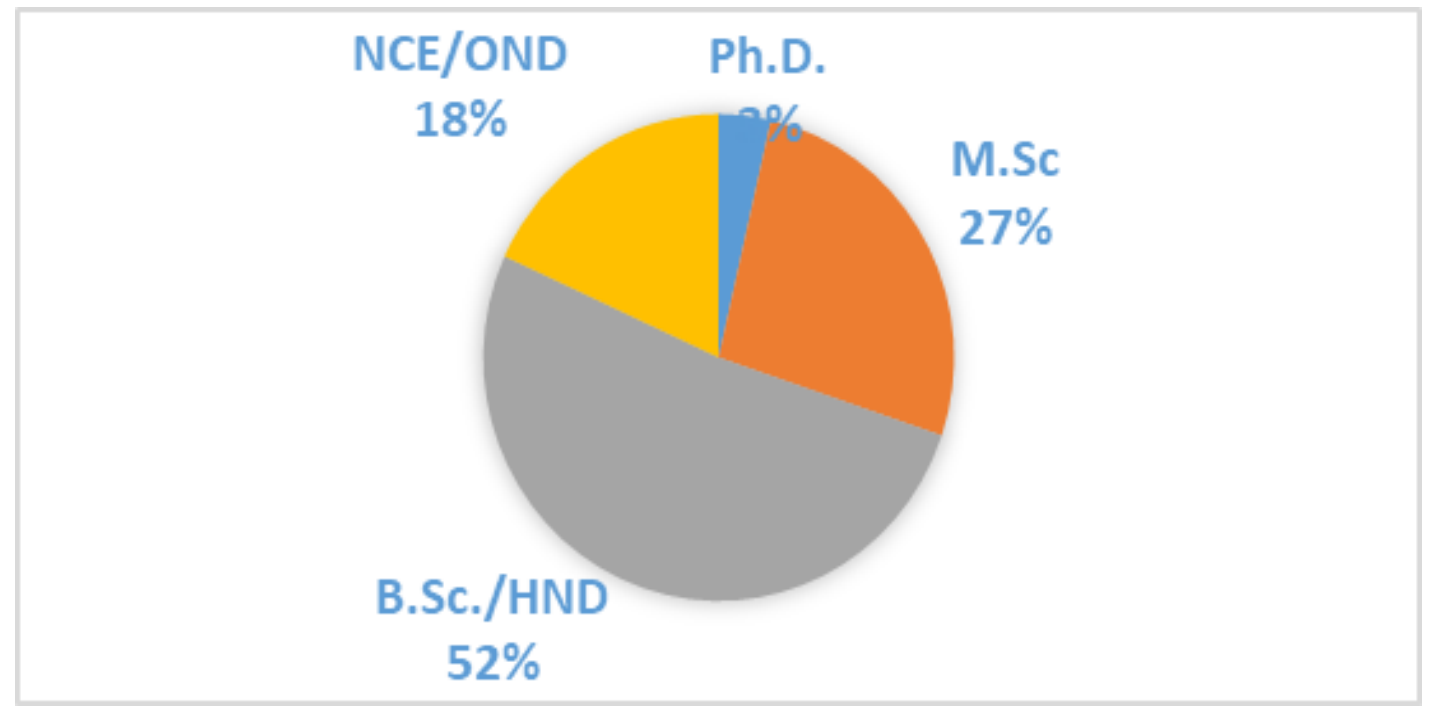

Figure 2: Educational Qualification of Respondents 


\subsection{Research Questions}

This section presents answers to the research questions raised in this study.

\section{Research Question 1: What is the citizens' level of awareness of Government 2.0?}

This section used the mean score of the responses to answer the question on citizens' level of awareness of Government 2.0. see Figure 3.

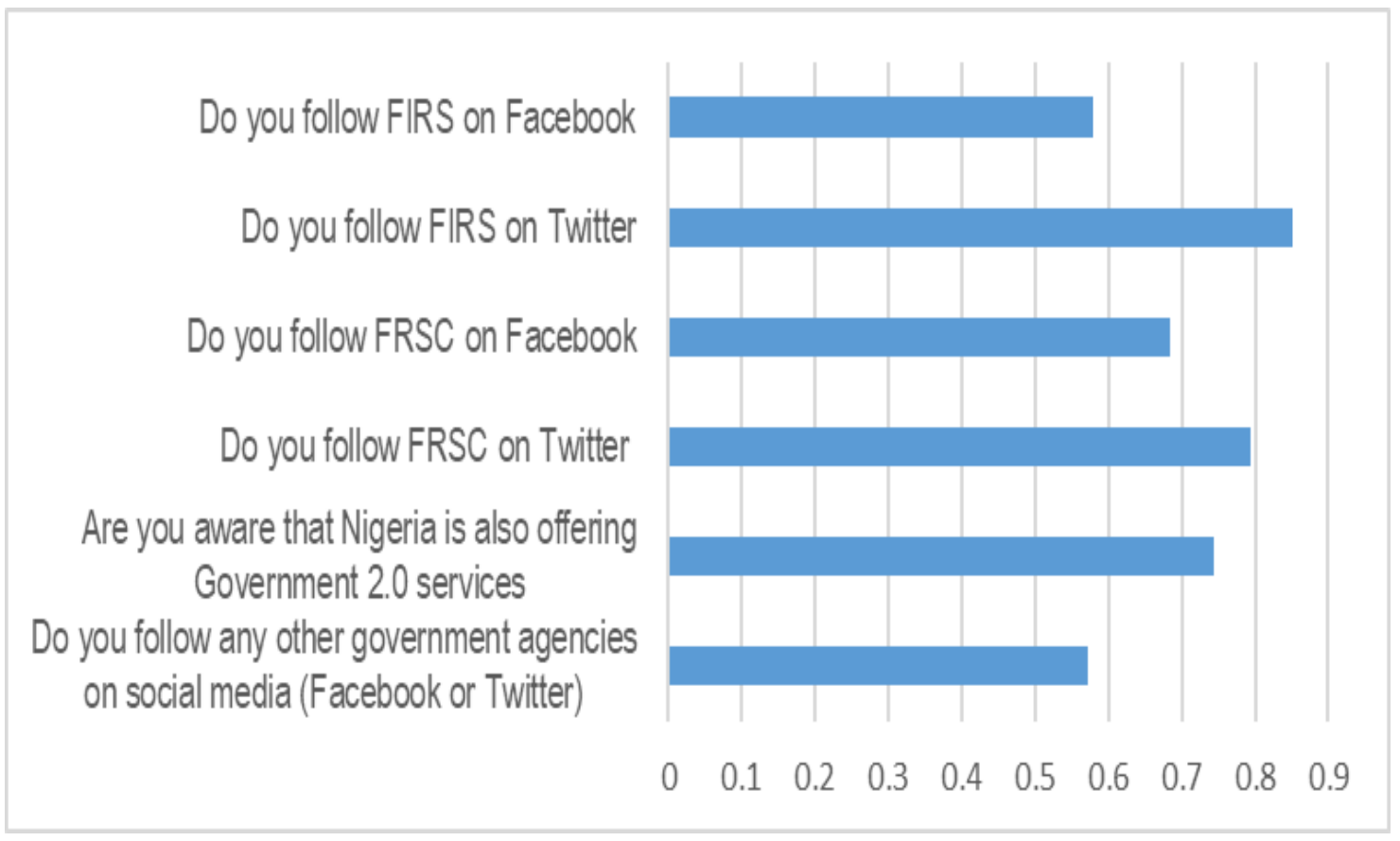

Figure 3: Citizens' Level of Awareness of Government 2.0

Figure 3 reveals that respondents at the two agencies show a high level of awareness. Although, the respondents' level of awareness of the FIRS Twitter handle is slightly higher ( $\bar{x}=0.851)$ than respondents' level of awareness of the FRSC Twitter ( $\overline{\mathrm{x}}=0.794)$.

However, respondents' awareness of the FRSC Facebook page ( $\bar{x}=0.685)$ is higher than that of FIRS $(\bar{x}=0.579)$. The mean scores for each of the questions posed on awareness are greater than 0.5 (half of the total mean obtainable).

Thus, it can be concluded that the citizens' level of awareness of Government 2.0 is high as the majority of respondents were affirmative of the statement. 
Research Ques 2: What is the level of citizens' perceived motivation towards the use of Government 2.0?

The different responses of respondents as regards the level of citizens' perceived motivation towards the use of Government 2.0 is presented in Table 3 and 4.

Table 3: Frequency Distribution of the Level of Citizens' Perceived Motivation (Intrinsic) Towards the Use of Government 2.0

\begin{tabular}{|c|c|c|c|c|c|}
\hline Incentives & \begin{tabular}{|l} 
Strongly \\
Disagree(\%)
\end{tabular} & Disagree(\%) & Agree (\%) & $\begin{array}{l}\text { Strongly } \\
\text { Agree (\%) }\end{array}$ & Mean \\
\hline It gives room for self-expression & $4(1.3 \%)$ & $49(15.8 \%)$ & $206(66.2 \%)$ & $52(16.7 \%)$ & 3.0804 \\
\hline $\begin{array}{l}\text { It allows for easy social interaction with } \\
\text { people }\end{array}$ & $7(2.3 \%)$ & $41(13.2 \%)$ & $184(59.2 \%)$ & $79(25.4 \%)$ & 3.0772 \\
\hline $\begin{array}{l}\text { It allows for social interaction with the } \\
\text { government }\end{array}$ & $9(2.9 \%)$ & $59(19.0 \%)$ & $160(51.4 \%)$ & $83(26.7 \%)$ & 3.0193 \\
\hline $\begin{array}{l}\text { I find the user interface attractive \& user } \\
\text { friendly }\end{array}$ & $9(2.9 \%)$ & $54(17.4 \%)$ & $200(64.3 \%)$ & $48(15.4 \%)$ & 2.9228 \\
\hline \multicolumn{6}{|l|}{ Accessibility } \\
\hline $\begin{array}{l}\text { It allows for easy social interaction with } \\
\text { people }\end{array}$ & $10(3.2 \%)$ & $30(9.6 \%)$ & $195(62.7 \%)$ & $76(24.4 \%)$ & 3.0836 \\
\hline $\begin{array}{l}\text { I find information disseminated to be } \\
\text { reliable }\end{array}$ & $5(1.6 \%)$ & $57(18.3 \%)$ & $167(53.7 \%)$ & $82(26.4 \%)$ & 3.0482 \\
\hline $\begin{array}{l}\text { I find information disseminated through } \\
\text { Twitter to be applicable and helpful for my } \\
\text { task }\end{array}$ & $7(2.3 \%)$ & $45(14.5 \%)$ & $191(61.4 \%)$ & $67(21.5 \%)$ & 3.0258 \\
\hline $\begin{array}{l}\text { I find Information disseminated to be exact } \\
\text { and precise }\end{array}$ & $11(3.5 \%)$ & $69(22.2 \%)$ & $151(48.6 \%)$ & $80(25.7 \%)$ & 2.9646 \\
\hline $\begin{array}{l}\text { I find information disseminated to be } \\
\text { sufficiently up to date }\end{array}$ & $4(1.3 \%)$ & $74(23.8 \%)$ & $165(53.1 \%)$ & $68(21.9 \%)$ & 2.9550 \\
\hline $\begin{array}{l}\text { I find information disseminated through } \\
\text { Facebook to be applicable and helpful for } \\
\text { my task }\end{array}$ & $7(2.3 \%)$ & $65(20.9 \%)$ & $179(57.6 \%)$ & $60(19.3 \%)$ & 2.9389 \\
\hline \multicolumn{6}{|l|}{ Ubiquity } \\
\hline $\begin{array}{l}\text { I can access new things/ information on the } \\
\text { social media page wherever I am }\end{array}$ & $5(1.6 \%)$ & $24(7.7 \%)$ & $192(61.7 \%)$ & $90(28.9 \%)$ & 3.1801 \\
\hline $\begin{array}{l}\text { I can use the social media page without } \\
\text { difficulty wherever I am }\end{array}$ & $5(1.6 \%)$ & $41(13.2 \%)$ & $177(56.9 \%)$ & $88(28.3 \%)$ & 3.1190 \\
\hline $\begin{array}{l}\text { I can access information at the best time } \\
\text { for me on their Twitter page }\end{array}$ & $11(3.5 \%)$ & $45(14.5 \%)$ & $169(54.3 \%)$ & $86(27.7 \%)$ & 3.0611 \\
\hline $\begin{array}{l}\text { I can access information at the best time } \\
\text { for me on their Facebook page }\end{array}$ & $10(3.2 \%)$ & $57(18.3 \%)$ & $167(53.7 \%)$ & \begin{tabular}{|l}
77 (24.8\%) \\
\end{tabular} & 3.0000 \\
\hline $\begin{array}{l}\text { The government Twitter page keeps me } \\
\text { informed at all times }\end{array}$ & $8(2.6 \%)$ & $74(23.8 \%)$ & $179(57.6 \%)$ & $50(16.1 \%)$ & 2.8714 \\
\hline $\begin{array}{l}\text { The government Facebook page keeps me } \\
\text { informed at all times }\end{array}$ & $10(3.2 \%)$ & $85(27.3 \%)$ & $166(53.4 \%)$ & $50(16.1 \%)$ & 2.8232 \\
\hline
\end{tabular}




\begin{tabular}{|l|l|l|l|l|l|}
\hline Interactivity \\
\hline $\begin{array}{l}\text { The social media page allows for two-way } \\
\text { communication between the visitors and } \\
\text { the page }\end{array}$ & $6(1.9 \%)$ & $37(11.9 \%)$ & $185(59.5 \%)$ & $83(26.7 \%)$ & 3.1093 \\
\hline $\begin{array}{l}\text { Information shared via the website has } \\
\text { provided additional knowledge and } \\
\text { enhanced learning }\end{array}$ & $6(1.9 \%)$ & $39(12.5 \%)$ & $183(58.8 \%)$ & $83(26.7 \%)$ & 3.1029 \\
\hline $\begin{array}{l}\text { Its Facebook and Twitter account is } \\
\text { effective in gathering visitors' feedback }\end{array}$ & $4(1.3 \%)$ & $46(14.8 \%)$ & $195(62.7 \%)$ & $66(21.2 \%)$ & 3.0386 \\
\hline $\begin{array}{l}\text { I find information that increases my } \\
\text { engagement in decision making on their } \\
\text { Facebook and Twitter account }\end{array}$ & $7(2.3 \%)$ & $68(21.9 \%)$ & $166(53.4 \%)$ & $70(22.5 \%)$ & 2.9614 \\
\hline $\begin{array}{l}\text { I find information disseminated through } \\
\text { Facebook and Twitter tailored to help } \\
\text { accomplish my tasks }\end{array}$ & $5(1.6 \%)$ & $73(23.5 \%)$ & $166(53.4 \%)$ & $65(20.9 \%)$ & 2.9417 \\
\hline $\begin{array}{l}\text { I concentrate on my task when using } \\
\text { government Facebook and Twitter account }\end{array}$ & $12(3.9 \%)$ & $72(23.2 \%)$ & $180(57.9 \%)$ & $47(15.1 \%)$ & 2.8424 \\
\hline
\end{tabular}

Table 3 shows the analysis of the different responses as regards the level of citizens' perceived motivation towards the use of Government 2.0. For this discussion, results from "Agree and strongly agree" options were combined as "Agree", while those from "Disagree and strongly disagree" options too were combined as "Disagree". Under incentives, $248(79.7 \%)$ respondents agreed that they find the FIRS and FRSC user interface attractive and user friendly, while $63(20.3 \%)$ disagreed. Also, $258(82.9 \%)$ respondents agreed that FIRS and FRSC Facebook and/or Twitter page gives room for self-expression while $53(17.1 \%)$ disagreed. Also, 263 $(84.6 \%)$ respondents agreed that it also allows for easy interaction with people while $49(15.4 \%)$ disagreed. Meanwhile, $243(78.1 \%)$ respondents agreed that the Facebook and/or Twitter page allows for social interaction with the government while $68(21.9 \%)$ disagreed.

Under Accessibility, it was revealed that $239(76.9 \%)$ revealed that they find information disseminated through Facebook to be applicable and helpful for their task while $52(23.2 \%)$ disagreed. Also, $258(82.6 \%)$ agreed that they find information disseminated through Twitter to be applicable and helpful for my task while $52(16.8 \%)$ disagreed. Likewise, 231 (74.3\%) agreed that they find information disseminated to be exact and precise while $80(25.7 \%)$ disagreed. Furthermore, it was discovered that $233(75 \%)$ agreed that they find information disseminated through Facebook and/or Twitter to be sufficiently up to date while $78(25.1 \%)$ Under ubiquity as an attribute of social media, it was discovered that $216(69.5 \%)$ agreed that the government Facebook page keeps them informed at all times while $95(30.5 \%)$ disagreed. Also, 229 (73.7\%) agreed that the government Twitter page keeps me informed at all times while $82(26.4 \%)$ disagreed. Meanwhile, $256(85.2 \%)$ agreed that they can use the social media page without difficulty wherever they are while $46(14.8 \%)$ disagreed.

Also, under interactivity as an attribute of social media $227(73 \%)$ respondents agreed that they concentrate on their task when using government Facebook and Twitter account while 84 (27.1\%). Also, 231 (74.9\%) respondents agreed that they find information disseminated through government Facebook and Twitter account tailored to help them accomplish their tasks while $78(25.1 \%)$ respondents disagreed. Also, $261(83.9 \%)$ agreed that the government Facebook and Twitter account is effective in gathering visitors' feedback while $50(16.1 \%)$ disagreed. Likewise, $266(85.5 \%)$ agreed that the Information shared via social media has provided additional knowledge and enhanced learning while $45(14.4 \%)$ disagreed. Furthermore, $268(86.2 \%)$ agreed that FIRS/FRSC social media page (Facebook and Twitter) allows for two-way communication between the visitors and the page while $43(13.8 \%)$ disagreed. 
Table 4: Frequency Distribution of the Level of Citizens' Perceived Motivation (Extrinsic) towards the Use of Government 2.0

\begin{tabular}{|c|c|c|c|c|c|}
\hline Virtual Social Identity & $\begin{array}{l}\text { Strongly } \\
\text { Disagree(\%) }\end{array}$ & Disagree(\%) & Agree (\%) & $\begin{array}{l}\text { Strongly } \\
\text { Agree (\%) }\end{array}$ & Mean \\
\hline $\begin{array}{l}\text { I use social media because it encourages } \\
\text { flexibility }\end{array}$ & $2(0.66 \%)$ & $25(8.0 \%)$ & $\begin{array}{l}163 \\
(52.4 \%)\end{array}$ & $\begin{array}{l}121 \\
(38.9 \%)\end{array}$ & 3.2958 \\
\hline $\begin{array}{l}\text { I actively use social media because it is } \\
\text { easy to use }\end{array}$ & $1(0.3 \%)$ & $25(8 \%)$ & $\begin{array}{l}183 \\
(58.8 \%)\end{array}$ & $102(32.8)$ & 3.2412 \\
\hline $\begin{array}{l}\text { I use social media because it has a } \\
\text { quality documentation process }\end{array}$ & $1(0.33 \%)$ & $47(15.1 \%)$ & $\begin{array}{l}182 \\
(58.5 \%)\end{array}$ & $81(26.0 \%)$ & 3.1029 \\
\hline $\begin{array}{l}\text { I use social media because of its lack of } \\
\text { biases }\end{array}$ & $8(2.6 \%)$ & $56(18.0 \%)$ & $\begin{array}{l}146 \\
(46.9 \%)\end{array}$ & $\begin{array}{l}101 \\
(32.9 \%)\end{array}$ & 3.0932 \\
\hline \multicolumn{6}{|l|}{ Virtual Altruism } \\
\hline $\begin{array}{l}\text { I obtain and share information from social } \\
\text { media }\end{array}$ & $3(1.0 \%)$ & $12(3.9 \%)$ & $\begin{array}{l}201 \\
(64.6 \%)\end{array}$ & $95(30.5 \%)$ & 3.2496 \\
\hline I interact well with other people online & $6(1.9 \%)$ & $33(10.6 \%)$ & $\begin{array}{l}175 \\
(56.3 \%)\end{array}$ & $97(31.2 \%)$ & 3.1672 \\
\hline $\begin{array}{l}\text { I share my knowledge with others via } \\
\text { social media }\end{array}$ & $9(2.9 \%)$ & $36(11.6 \%)$ & $\begin{array}{l}162 \\
(52.1 \%)\end{array}$ & $\begin{array}{l}104 \\
(33.4 \%)\end{array}$ & 3.1608 \\
\hline $\begin{array}{l}\text { I provide help for people in a real crisis or } \\
\text { who need online }\end{array}$ & $4(1.3 \%)$ & $47(15.1 \%)$ & $\begin{array}{l}165 \\
(53.1 \%)\end{array}$ & $95(30.5 \%)$ & 3.1286 \\
\hline $\begin{array}{l}\text { I take information obtained from social } \\
\text { media as tangible }\end{array}$ & $5(1.6 \%)$ & $61(19.6 \%)$ & $\begin{array}{l}144 \\
(46.3 \%)\end{array}$ & $\begin{array}{l}101 \\
(32.5 \%)\end{array}$ & 3.0965 \\
\hline \multicolumn{6}{|l|}{ Virtual Telepresence } \\
\hline $\begin{array}{l}\text { I meet and interact with more people } \\
\text { using social media }\end{array}$ & $2(0.6 \%)$ & $36(11.6 \%)$ & $\begin{array}{l}188 \\
(60.5 \%)\end{array}$ & $85(27.3 \%)$ & 3.1447 \\
\hline $\begin{array}{l}\text { Social media creates or facilitates the } \\
\text { building of virtual network and } \\
\text { communities }\end{array}$ & $3(1.0 \%)$ & $9(2.9 \%)$ & $\begin{array}{l}188 \\
(60.5 \%)\end{array}$ & $\begin{array}{l}111 \\
(35.7 \%)\end{array}$ & 3.0387 \\
\hline $\begin{array}{l}\text { Social media is an entirely different } \\
\text { society to me }\end{array}$ & $23(7.4 \%)$ & $38(12.2 \%)$ & $154(49.5 \%)$ & $96(30.9 \%)$ & 3.0386 \\
\hline
\end{tabular}

Table 4 shows that for virtual social identity, 295(91.6\%) respondents agreed that they actively use social media because it is easy to use while $26(8.4 \%)$ disagreed. Also, $263(84.5 \%)$ respondents agreed that they use social media because it has a quality documentation process while $48(18.1 \%)$ disagreed. Meanwhile, $247(79.8 \%)$ respondents agreed that they use social media because of its lack of biases while $64(20.6 \%)$ disagreed. Under virtual altruism social media as an individual characteristic, $296(95.1 \%)$ respondents agreed that they obtain and share information from social media while $15(4.9 \%)$ disagreed. Also, $266(85.5 \%)$ respondents agreed that they share their knowledge with others via social media while $45(14.5 \%)$ disagreed. Furthermore, $260(83.6 \%)$ agreed respondents that they provide help for people in a real crisis or need online while 51 (16.4\%)

Finally, under virtual telepresence, it was revealed that $273(87.8 \%)$ respondents meet and interact with more people using social media while $38(12.2 \%)$ disagreed. Also, $299(96.2 \%)$ respondents agreed that social media creates or facilitates the building of virtual network and communities while $12(3.9 \%)$ disagreed. Likewise, 260 $(80.4 \%)$ respondents agreed that social media is an entirely different means of communication to them while 61 $(19.6 \%)$ disagreed. Conclusively, it is deduced from the findings that there is a high level of citizens' perception towards the use of Government 2.0. 


\subsection{Test of Hypothesis}

The following were the results of the test of hypotheses:

$\mathrm{H}_{01}$ : Citizens' awareness does not significantly influence their continual usage intention of Government 2.0 .

The influence of awareness on continual usage intention of Government 2.0 was tested using simple linear regression analysis and the result is presented in Table 5.

Table 5: Regression Co-Efficient Analysis of Awareness on Continual Usage Intention of Government 2.0

\begin{tabular}{|c|c|c|c|c|c|c|}
\hline Agencies & \multirow[t]{2}{*}{ Model } & \multicolumn{2}{|c|}{$\begin{array}{l}\text { Unstandardized } \\
\text { Coefficients }\end{array}$} & \multirow{2}{*}{$\begin{array}{c}\text { Standardized } \\
\text { Coefficient }\end{array}$} & \multirow[b]{2}{*}{$\begin{array}{ll}T \\
\end{array}$} & \multirow[b]{2}{*}{ Sig. } \\
\hline \multirow[b]{3}{*}{ FRSC } & & B & Std. Error & & & \\
\hline & (Constant) & 8.016 & .366 & & 21.877 & .000 \\
\hline & Awareness & .487 & 122 & .273 & 4.009 & .000 \\
\hline & (Constant) & 7.881 & .525 & & 14.999 & .000 \\
\hline FIRS & Awareness & .482 & .185 & .246 & 2.599 & .011 \\
\hline & (Constant) & 7.923 & .293 & & 27.004 & .000 \\
\hline $\begin{array}{l}\text { Both } \\
\text { Agencies }\end{array}$ & Awareness & .496 & .100 & .274 & 4.976 & .000 \\
\hline
\end{tabular}

Dependent variable: Continual usage intention of Government 2.0

Table 5 reveals that awareness of citizens' at FRSC, and FIRS has a significant influence on continual usage intention $(\beta=.273, p<.05, \beta=.246, p<.05)$ respectively. Also when the data for the two agencies were combined, there is a significant influence of awareness on continual usage intention of Government $2.0(\beta=.274, p<.05)$. This result implies that awareness will significantly increase citizens' continual usage intention of Government 2.0.

\section{Hypothesis 2:}

$\mathrm{H}_{02}$ : Extrinsic motivation (incentives, accessibility, and social media attributes) does not significantly influence citizens' continual usage intention of Government 2.0.

The influence of extrinsic motivation on continual usage intention of Government 2.0 was tested using simple linear regression analysis and the result is presented in Table 6 and 7.

Table 6: Regression co-efficient analysis of extrinsic motivation on continual usage intention of Government 2.0

\begin{tabular}{|l|l|r|r|r|r|r|}
\hline \multirow{2}{*}{ Agencies } & \multirow{2}{*}{ Model } & \multicolumn{2}{|c|}{$\begin{array}{c}\text { Unstandardized } \\
\text { Coefficients }\end{array}$} & $\begin{array}{l}\text { Standardized } \\
\text { Coefficient B }\end{array}$ & T & Sig. \\
\cline { 3 - 7 } & & \multicolumn{1}{|c|}{ B } & \multicolumn{1}{c|}{ Std. Error } & Beta & & \\
\hline \multirow{3}{*}{ FRSC } & (Constant) & 1.411 & .670 & & 2.106 & .036 \\
\cline { 2 - 7 } & Extrinsic motivation & .119 & .010 & .648 & 12.025 & .000 \\
\hline \multirow{3}{*}{ FIRS } & (Constant) & 3.951 & .940 & & 4.205 & .000 \\
\cline { 2 - 7 } $\begin{array}{l}\text { Both } \\
\text { Agencies }\end{array}$ & Extrinsic motivation & .081 & .014 & .484 & 5.637 & .000 \\
\cline { 2 - 7 } & Extrinsic motivation & .454 & .541 & & 4.538 & .000 \\
\hline
\end{tabular}

Dependent variable: Continual usage intention of Government 2.0 
Table 6 reveals that the extrinsic motivation of citizens at FRSC and FIRS has a significant influence on their continual usage intention $(\beta=.648, p<.05, \beta=.484, p<.05 ;)$ respectively. When the data for the two agencies were combined, the result shows there is also a significant influence of extrinsic motivation on continual usage intention of Government $2.0(\beta=.590, p<.05)$. This result implies that extrinsic motivation significantly influences the continual usage intention of Government 2.0.

Since extrinsic motivation was made up of accessibility, incentives, social media attributes, the influence of the three subcontracts on citizens' continual usage intention of Government 2.0 were examined. The results show that accessibility, incentives, social media attributes have significant influences on the continual usage intention of Government 2.0.

Table 7: Regression co-efficient analysis of extrinsic motivation (incentives, accessibility, social media attributes) on continual usage intention

\begin{tabular}{|c|c|c|c|c|c|c|}
\hline \multirow{6}{*}{$\begin{array}{l}\text { Both } \\
\text { Agencies }\end{array}$} & \multirow[t]{2}{*}{ Model } & \multicolumn{2}{|c|}{$\begin{array}{l}\text { Unstandardized } \\
\text { Coefficients }\end{array}$} & \multirow{2}{*}{$\begin{array}{c}\text { Standardized } \\
\text { Coefficient }\end{array}$} & \multirow[b]{2}{*}{$T$} & \multirow[b]{2}{*}{ Sig. } \\
\hline & & B & Std. Error & & & \\
\hline & (Constant) & 2.492 & .539 & & 4.624 & .000 \\
\hline & Incentives & .153 & .034 & .236 & 4.465 & .000 \\
\hline & Accessibility & .168 & .045 & .259 & 3.710 & .000 \\
\hline & $\begin{array}{l}\text { Social Media } \\
\text { Attribute }\end{array}$ & .067 & .022 & .219 & 3.049 & .002 \\
\hline
\end{tabular}

Dependent variable: Continual usage intention of Government 2.0

Table 7 shows that incentives $(\beta=.236, p<.05)$, accessibility $(\beta=.259, p<.05)$, social media attributes $(\beta=.219$, $p<.05)$, all had significant influences on continual usage intention of Government 2.0.

\section{HYPOTHESIS 3:}

$\mathrm{H}_{03}$ : Intrinsic motivation (virtual social identity, virtual altruism, and virtual telepresence) does not significantly influence citizens' continual usage intention of Government 2.0.

The influence of the Intrinsic motivation factor on continual usage intention was tested using simple linear regression analysis and the result is presented in Table 8.

Table 8: Regression co-efficient analysis of intrinsic motivation factors on continual usage intention

\begin{tabular}{|l|l|r|r|r|r|r|}
\hline \multirow{2}{*}{ Agencies } & \multirow{2}{*}{ Model } & \multicolumn{2}{|c|}{$\begin{array}{c}\text { Unstandardized } \\
\text { Coefficients }\end{array}$} & $\begin{array}{c}\text { Standardized } \\
\text { Coefficient B }\end{array}$ & T & Sig. \\
\cline { 3 - 7 } & & \multicolumn{1}{c|}{ B } & Std. Error & \multicolumn{1}{c|}{ Beta } & & \\
\hline \multirow{3}{*}{ FRSC } & (Constant) & 3.383 & .884 & & 3.827 & .000 \\
\cline { 2 - 7 } & Intrinsic Motivation & .158 & .023 & .434 & 6.856 & .000 \\
\hline \multirow{3}{*}{ FIRS } & (Constant) & 3.544 & 1.216 & & 2.916 & .004 \\
\cline { 2 - 7 } Both Agencies & Intrinsic Motivation & .148 & .032 & .415 & 4.672 & .000 \\
\cline { 2 - 7 } & (Constant) & 3.519 & .710 & & 4.954 & .000 \\
\cline { 2 - 7 } & Intrinsic Motivation & .152 & .019 & .423 & 8.204 & .000 \\
\hline
\end{tabular}

Dependent variable: Continual usage intention of Government 2.0

Intrinsic motivation of citizens at FRSC, and FIRS has a significant influence on their continual usage intension of Government $2.0(\beta=.434, p<.05, \beta=.415, p<.05)$ respectively. Table 8 further reveals that when the data for both agencies were combined, there is a significant influence of intrinsic motivation on citizens' continual usage intention of Government $2.0(\beta=.423, p<.05)$. 
Further analysis was conducted to see if each sub-construct in intrinsic motivation show any influence on citizens' continual usage intention of Government 2.0. Table 9 shows that except for virtual altruism $(\beta=.042$, $p>.05)$, both the virtual social identity $(\beta=.294, p<.05)$, and virtual Telepresence $(\beta=.201, p<.05)$ showed significant influence on citizens' continual usage intention of Government 2.0.

Table 9: Regression co-efficient analysis of intrinsic motivation (virtual social identity, virtual altruism, virtual telepresence) on continual usage intention of Government 2.9

\begin{tabular}{|c|c|c|c|c|c|c|}
\hline \multirow{6}{*}{$\begin{array}{l}\text { Both } \\
\text { Agencies }\end{array}$} & \multirow[t]{2}{*}{ Model } & \multicolumn{2}{|c|}{$\begin{array}{l}\text { Unstandardized } \\
\text { Coefficients }\end{array}$} & \multirow{2}{*}{$\begin{array}{c}\text { Standardized } \\
\text { Coefficient B } \\
\text { Beta }\end{array}$} & \multirow[b]{2}{*}{$\mathrm{T}$} & \multirow[b]{2}{*}{ Sig. } \\
\hline & & B & Std. Error & & & \\
\hline & (Constant) & 3.055 & .730 & & 4.186 & .000 \\
\hline & Virtual social identity & .267 & .059 & .294 & 4.557 & .000 \\
\hline & Virtual Altruism & .029 & .048 & .042 & .601 & .548 \\
\hline & Virtual Telepresence & .251 & .075 & .201 & 3.343 & .001 \\
\hline
\end{tabular}

The result from Table 9, shows that citizens with higher virtual social identity and virtual telepresence will likely increase their continual usage intention of Government 2.0.

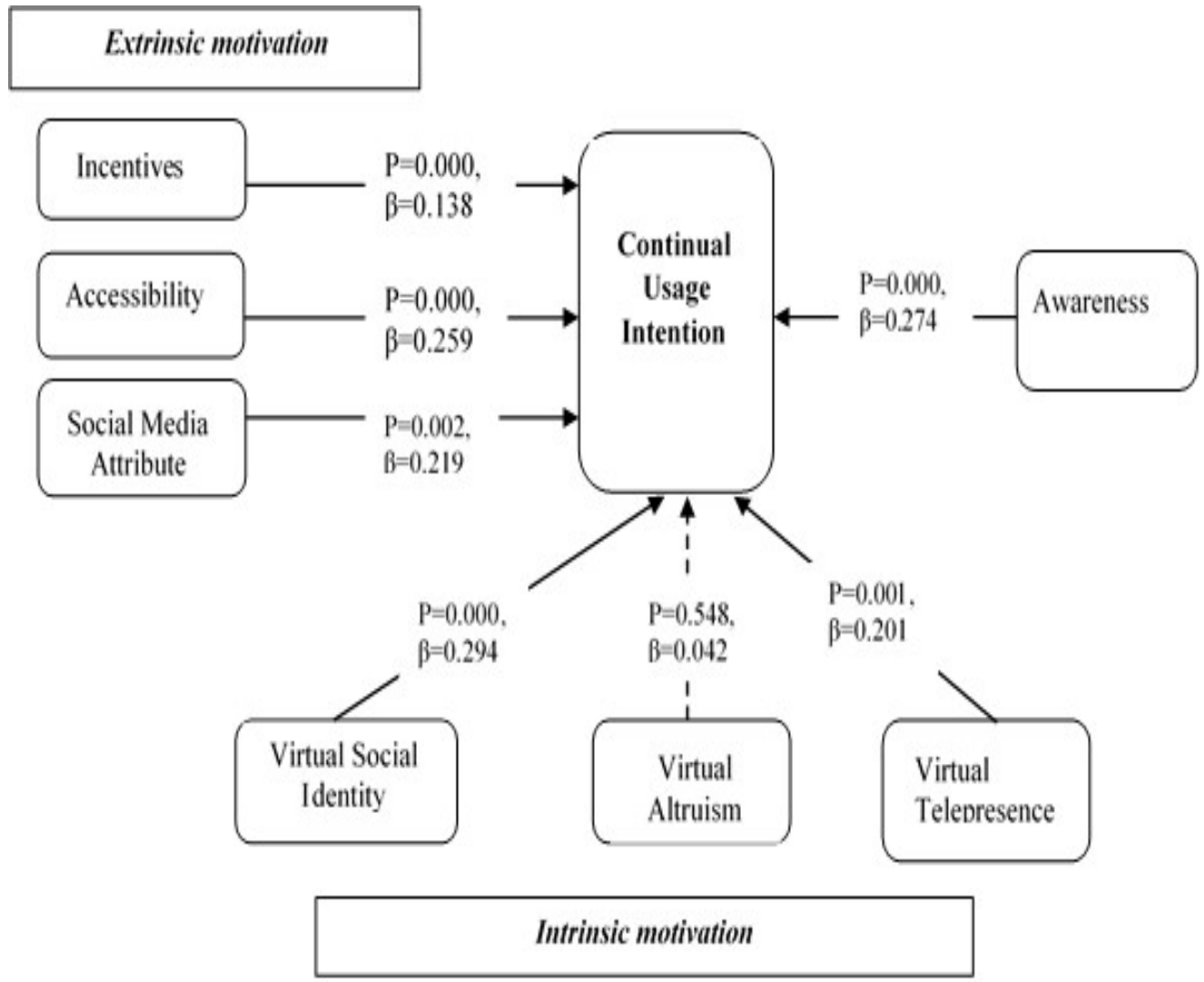

Figure 4: Resultant Research Model 
The Resultant Research Model (Figure 4) shows that awareness; extrinsic motivation factors (Incentives, Accessibility, Social Media Attributes), and intrinsic motivation factors (Virtual Social Identity, Virtual Telepresence) will promote continual usage intention of Government 2.0 as shown by the black arrowed line. Only Virtual Altruism does not show an influence on citizens' continual usage intention of Government 2.0 as shown by the hashed and dotted line in the Resultant Research Model.

\section{DISCUSSION OF FINDINGS}

The findings of this study reveal that the level of awareness of Government 2.0 by citizens is high indicating that the majority of the respondents were aware that Nigeria is offering Government 2.0 services. The findings align with that of Dungse, Mato, Makinde and Chidozie (2018) which stated that usage of social media with reference to Twitter as a tool for political participation in governance in Nigeria is high. It also agrees with that of Tumin and Fung (2010) who stated that there was a high level of awareness of Government 2.0 services among citizens. The study shows that awareness has a significant relationship and influence on citizens' continual usage intention. This finding corroborates with that of Sipior and Ward (2013) who reported that awareness of government websites is significantly related to their usage. It is also in alignment with the findings of Oyetola, Omotayo \& Nwobu (2018) who stated that the awareness of the government information portal is relevant to its usage; the higher the awareness, the higher the usage.

With regards to the level of citizens' perceived motivation, the findings of this study reveal that majority of the respondents have a positive perception of motivation towards the use of Government 2.0, also that the level of perception is high as the majority of the respondents agreed that the government (FIRS/FRSC) Facebook and/or Twitter pages give room for self-expression and social interaction between the citizens and the government. However, despite the high level of perceived motivation, quite many respondents did not agree that they find information that increases their engagement in decision making on FIRS/FRSC Facebook pages and Twitter accounts and that they find information disseminated not to be sufficiently up to date. ALotaibi, Ramachandran, Kor and Hosseinian-Far (2018) opined that there is a need for government to deliver tangible and relevant information that will promote citizens' participation in decision making. Also, Shipps and Philips (2013) also concluded that creating a platform where users are attracted, involved and enlightened will increase user's interaction and satisfaction, these have implications for continual usage intention of Government 2.0 by the citizens.

This study also reveals that there was a significant influence of extrinsic and intrinsic motivation on continual usage intention. This finding corroborates with the results of Jiang et al. (2016) who stated that social identity influences continual usage intention. It also aligns with that of Chang \& Chin (2011) who stated that intention usage is significantly affected by intrinsic and extrinsic motivations.

\section{CONCLUSION}

Without effective awareness creation targeted at different categories of people in the society, the successful implementation of Government 2.0 platforms by governments at all levels of governance cannot be made possible. Underlying citizens' intention to use Government 2.0 in Nigeria, its adoption is well predicted by factors of awareness, extrinsic and intrinsic motivations as revealed in this study. For decision makers in government to get people to use and adopt Government 2.0, these services must be genuinely useful to the intended users. 


\section{RECOMMENDATIONS}

Based on the findings of this study, the following recommendations are made:

1. government should conduct awareness campaigns periodically targeting potential users. This is because people will use services that they are aware of.

2. government should emphasise the usefulness and benefits of Government 2.0 to citizens as this will motivate more citizens to use it.

3. there is a need for government to enhance the functionalities and features of Government 2.0 for the use of citizens.

4. the use of incentives such as lower costs for services, time and effort savings, reduction in bureaucratic procedures and enabling everybody to conduct governmental transactions on an equal basis should be incorporated into government social media account. These will motivate more people to use government social media accounts.

5. Other motivational incentives such as accessibility, open data and shared knowledge should be incorporated into government social media account as this will motivate citizens to use the services continually.

6. Government 2.0. services must be efficient and should meet the specific needs of citizens. When needs are met, there is a high likelihood that citizens will continue to use such Government 2.0. services. 


\section{REFERENCES}

1. Abdulkareem A. K. (2016), Challenges of E-Government Implementation in the Nigerian Public Service. Journal of Creative Writing,1(4), 45-56.

2. Abdulkareem A. K., \& Ishola A. A. (2016). E-government in Nigeria: Progress and Prospects. Ilorin Journal of Administration and Development, 2(1).

3. Agourram H. (2013). The Impact of National Culture on Online Social Network Usage and Electronic Commerce Transactions. European Scientific Journal, 9(19).

4. Aladalah M., Yen C. \& Lee V. (2015). Enabling Citizen Participation in Government 2.0: An Empowerment Perspective. Electronic Journal of e-Government, 13(2). Retrieved 20 April, 2019 from http://www.ejeg.com/issue/download.html?idArticle=409

5. AlAwadhi S. \& Morris A. (2008). The Use of the UTAUT Model in the Adoption of E-government Services in Kuwait Proceedings of the 41st Hawaii International Conference on System Science, Waikoloa, USA

6. ALotaibi R. M., Ramachandran M., Kor A. \& Hosseinian-Far A. (2018). Factors Affecting Citizens' Use of Social Media to Communicate with the Government: A Proposed Model. Electronic Journal of eGovernment, 14(1), 1477-7029.

7. Alrashidi A. (2012). User Acceptance and Motivation of E-Governance Services Based on Employees Levels of Experience in the UAE SME. American Journal of Economics 2, 132-135 retrieved from https://www.researchgate.net/publication/314589890

8. AL-Shehry A., Rogerson S. N. \& Fairweather N.B. (2006). The Motivations for Change Towards Egovernment Adoption: Case Studies from Saudi Arabia. eGovernment Workshop. Retrieved on 10 January, 2019

from http://citeseerx.ist.psu.edu/viewdoc/download?doi=10.1.1.106.6960\&rep=rep1\&type=pdf

9. Ayoade O. B. (2019). Effect of E-Governance Usage on Service Delivery in Tertiary Institutions in Oyo Township of Southwest Nigeria. African Journal of Management Information, 1(3), pp. 37 - 56.

10. Bakare B.I., Ekanem I.A. \& Allen I.O. (2017). Appraisal of Global System for Mobile Communication (GSM) In Nigeria. American Journal of Engineering Research, 6(6), pp 97-102.

11. Baker P., Fairchild A., Pater J. \& Seavey A. (2010). Community, Participation and Virtual Spaces: Design Considerations for Inclusivity. In Proceedings of the 10th European Conference on eGovernment, Limerick, Ireland.

12. Bertot J. C., Jaeger P. T., Munson S., \& Glaisyer, T. (2010). Social Media Technology and Government Transparency. Computer, 43(11), 53-59.

13. BwalyaK. J. \& Mutula S. M. (2014). E-government: implementation, adoption and synthesis in developing countries, 1. Berlin/Munich: De Gruyter Saur. ISBN 978-3-11-030475-6

14. Chang C., \& Chin Y. (2011) Predicting the usage intention of social network games: an intrinsic-extrinsic motivation theory perspective. Annual Conference on Innovations in Business \& Management London, UK. Retrieved from https://www.researchgate.net/publication/220449381

15. Chen H. (2012). Relationship between Motivation and Behaviour of SNS User. Journal of Software, $7(6), 1265-1272$.

16. Chui M., Miller A., \& Roberts R. P. (2009). Six Ways to Make Web 2.0 Work. The McKinsey Quarterly, $1-7$.

17. Chun S. A., Shulman S. W., Almazan R. S., \& Hovy, E. (2010). Government 2.0: Making connections between citizens, data and government. Information Polity, 15, pp 1-9.

18. Coskunçay D. F. (2013). Identifying the Factors Affecting Users' Adoption of Social Networking. International Journal of Human-Computer Interaction, 4(1), 1-18.

19. Demircioglua M. A. \& Chen C. (2019), Public Employees' Use of Social Media: Its Impact on Need Satisfaction and Intrinsic Work Motivation. Government Information Quarterly 36, (1), pp 51-60 
20. Dungse Y., Mato S., Makinde O. \& Chidozie F. (2018). Social Media, Political Mobilisation and Participatory Politics in Nigeria. Paper presented at 5th Covenant University Conference on EGovernance in Nigeria, Covenant University, Ota, Nigeria.

21. Eggers W. D. (2004). Government 2.0: using technology to improve education, cut red tape, reduce gridlock, and enhance democracy. ISBN 9780742541757, Rowman \& Littlefield: New York, U.S.A.

22. Fang Y. H. \& Chiu, C. M. (2010). In justice we Trust: Exploring Knowledge-Sharing Continuance Intentions in Virtual Communities of Practice. Computers in Human Behavior, 26, 235-246.

23. Gay L. R., \& Airasian P. (2003). Educational Research: Competencies for Analysis and Application (7th ed.). Pearson Education

24. Grimmelikhuijsen S.G. (2008). What Drives Transparency of Municipal Governments: Push or Pull? Paper presented at the European Group for Public Administration (EGPA) Conference on September 35,2008 , Rotterdam.

25. Humphrey N. (1997). Varieties of Altruism - and the Common Ground between Them. Social Research, 64(2), 199-209.

26. Ibikunle F. \& Sarumi J. (2012). Electronic-Governance for Nigeria: Opportunities and Challenges in the Digital Era, International Journal of Electronic Governance and Research 1 (1), pp. 77-84.

27. Ingrams A., Manoharan, A. Schmidthuber L. \& Holzer M. (2018). Stages and Determinants of EGovernment Development: A Twelve-Year Longitudinal Study of Global Cities. International Public Management Journal, 23(6), 731-769, DOI: 10.1080/10967494.2018.1467987

28. Isiani M. C. \& Obi-Ani N. (2019). Amalgamation of Northern and Southern Protectorates of Nigeria: Blessing or Curse. International journal of development and sustainability, 13, 145-158.

29. Jiang C., Zhao W., Sun X., Zhang K., Zheng R., \& Qu W. (2016). The Effects of the Self and Social Identity on the Intention to Microblog: An Extension of the Theory of Planned Behavior. Computers in Human Behavior, 64(2), pp 754-759.

30. Kaplan A. M. \& Haenlein M. (2010). Users of the World, Unite! The Challenges and Opportunities of Social Media. Business Horizons, 53(1), 61. Retrieved on 10 August 2018 from http://scihub.tw/10.1016/i.bushor.2009.09.003

31. Kwon O. \& Wen Y. (2010). An Empirical Study of the Factors Affecting Social Network Service Use. Computers in Human Behavior, 26(2), 254-263. Retrieved from http://scihub.tw/https://doi.org/10.1016/i.chb.2009.04.011

32. Lallana E. (2008). E-government for Development Information Exchange. Institute for Development Policy and Management. Retrieved on 15 April, 2019 from http://www.egov4dev.org/mgovernment/evaluation/

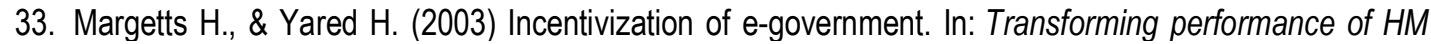
Customs and Excise through electronic service delivery. UK National Audit Office Report by the Comptroller and Auditor General, HC 1267 Session 2002-2003, 20 Nov.

34. Meijer A., Grimmelikhuijsen S. \& Brandsma G. J. (2012). Communities of Public Service Support: Citizens Engage in Social Learning in Peer-To-Peer Networks. Government Information Quarterly, 29(1), pp 21-29.

35. Meijer A.J., Koops B., Pieterson W., Overman S. \& Tije S. (2012). Government 2.0: Key Challenges to Its Realization. Electronic Journal of e-Government, 10 (1), 1-11.

36. Mergel I., Schweik C. M. \& Fountain, J. E. (2009). The Transformational Effect of Web 2.0 Technologies on Government. SSRN 1412796.

37. Naeem I. (2014). Evolution of New Media. New Media, Democracy \& Development. Retrieved on 10 February, 2019 from https://wpmu. mah.se/nmict142group4/

38. Nwana O. C. (1981). Introduction to Education Research for Student Teachers. Heinemann Educational Books 
39. Ogunsola K. \& Olojo T.P. (2020). Towards Connected Governance: Case Studies of Factors Influencing Citizens' Continuance Usage Intention of Web 2.0. in Nigeria. Ed. by Mahmood Z. Accepted in Web 2.0 and Cloud Technologies for Implementing Connected Government, IGI Global.

40. Ogunsola K. \& Ojebola T. (2017). Users' Assessment of the Quality of Information Disseminated through Facebook by Selected Law Enforcement Agencies in Nigeria. Electronic Government, an International Journal, Inderscience Publishers Limited, Olney, 13(2), pp. 129-147

41. Ogunsola K. \& Tiamiyu M. A. (2017). Assessment of Levels and Interrelationships of ICT Deployment, Web Readiness, and Web Presence Quality of Nigerian E-Government Websites. Handbook of Research on Sustainable ICT Adoption and Integration for Socio-Economic Development, IGI Global, pp 1-30.

42. Oyetola O., Omotayo O. \& Nwobu B. (2018). Awareness and Perception of E-Governance Information Portal by Undergraduates of University of Lagos, Nigeria. International Journal of Academic Library and Information Science, 6(7), 213-221

43. Ramírez-Correa P. E., Rondán-Cataluña F. J. \& Arenas-Gaitán J. (2013). Exploring Factors that Affect the Adoption of Social Networks Services by Generation Y in Chile. Interciencia, 38(9), 628-633

44. Reddick C. G. \& Aikins S. K. (2017). Web 2.0 Technologies and Democratic Governance Public Administration and Information Technology (1) retrieved from https://www.researchgate.net/publication/302223096

45. Ryan R. M. and Edward L. Deci E. L. (2000). Self-Determination Theory and the Facilitation of Intrinsic Motivation, Social Development, and Well-Being. American Psychologist, (55)1, 68-78 DOl: 10.1037110003-066X.55.1.68

46. Shao G. (2009). Understanding the Appeal of User-Generated Media a Uses and Gratification Perspective. Internet Research, 19, 7-25.

47. Shipps B. \& Philips B. (2013). Social Networks, Interactivity and Satisfaction: Assessing SocioTechnical Behavioral Factors as an Extension to Technology Acceptance. Journal of Theoretical and Applied Electronic Commerce Research, 8(1):35-52. https://doi.org/10.4067/S071818762013000100004

48. Sipior J. C \& Ward B. T. (2013). E-government Awareness and Visitation among the Digitally Disadvantaged. Journal of Internet Commerce, 12, 26-47.

49. Sivarajah U., Irani Z. \& Weerakkody V. (2015). Evaluating the use and Impact of Web 2.0 Technologies in Local Government. Government Information Quarterly, (4), pp 473-487

50. Stafford M. R. \& B. Stern (2002). Consumer Bidding Behaviour on Internet Auction Sites. International Journal of Electronic Commerce, 7(1), pp. 135-150.

51. Tajfel H., \& Turner J. C. (1979). An integrative theory of inter-group conflict. In Austin W. G. \& Worchel S. (Eds.), The social psychology of inter-group relations Pp. 33-47 Monterey, CA: Brooks/Cole.

52. Tiamiyu, M.A. and Ogunsola, K. (2008). Preparing for E-Government: Some Findings and Lessons from Government Agencies in Oyo State, Nigeria. South Africa Journal of Libraries and Information Science, Vol. 74, No. 1, pp. 58-72.

53. Tumin Z. \& Fung A. (2010). From Government 2.0 to Society 2.0: Pathways to Engagement, Collaboration and Transformation. Retrieved on from 10 June 2019

https://ash.harvard.edu/files/from_government_2.0.pdf

54. Urbina A. \& Abe N. (2017). Citizen-centric Perspective on the Adoption of E-Government in the Philippines. The Electronic Journal of e-Government, 15(2), 63-83.

55. Verdegem P. \& Verleye G. (2009). User-centred E-Government in Practice: a Comprehensive Model for Measuring User Satisfaction. Government Information Quarterly, $26 . \quad 487-497$. 10.1016/j.giq.2009.03.005. 